\title{
Создание фенотипических химер кур с использованием бластодермальных клеток пород брама светлая и брама палевая
}

Козикова Л.в., доктор биологических наук, ведущий научный сотрудник лаборатории молекулярной генетики Полтева Е.А., младший научный сотрудник лаборатории молекулярной генетики

Всесоюзный научно-исследовательский институт генетики и разведения сельскохозяйственных животных (ВНИИГРж) - филиал ФГБНУ «Федеральный исследовательский центр животноводства - ВИЖ имени академика Л.К. Эрнста», Санкт-Петербург, Пушкин

\begin{abstract}
Аннотация: Разъитие клеточных и генных технологий позболяет получать генетически новые организмы, способствовать разнообразию пород и создабать уникальных химерных и трансгенных птии. Методом трансплантации эмбриональных клеток были получены межпородные химеры брамы сбетлой и брамь палевой. Наибольшее количество химер было выявлено при сочетании брама палебая - донор, брама светлая - реципиент (42,9\%), тогда как при обратном сочетании этих же пород эффектибность получения химерных особей была 63 раза меньше. Причинами могли служить как технические сбои, так и особенности бзаимодействия клеток разной генетической природы, объединенных $\mathcal{6}$ один организм. В среднем, эффрективность получения химерных птии 6 этой серии экспериментов составила 28, 15\%. Дана фенотипическая характеристика химер. Разработанный метод получения инбекционных химер кур может найти широкое применение 6 экспериментальной эмбриологии, криобиологии, трансгенезе, ветеринарии и птицеводстве.
\end{abstract}

Ключебые слоба: химеры, доноры, реципиенты, породы кур, трансплантация, бластодермальные клетки, фенотип.

Введение. Известно, что интенсивный генетический отбор птицы ведет к появлению разных фенотипов. Примером могут служить бройлеры с прекрасно развитой мышечной системой, что важно для интенсивного развития мясного птицеводства. Для кур-несушек характерно развитие репродуктивной системы, обеспечивающей получение значительного количества яиц. Тем не менее, одним из барьеров для создания новых экологически чистых пород и кроссов птицы является снижение породного разнообразия, особенно в промышленных линиях [1]. Интенсивное развитие клеточных и генных технологий позволяет получать генетически новые организмы с уни- кальными фенотипами, такие как химеры и трансгенные птицы [2]. Птицы требуют особого подхода при создании химер из-за особого эмбрионального развития с наличием огромного количества желтка. Химерные организмы характеризуются наличием генетически различающихся клеток, полученных от разных особей. Довольно часто химерных и трансгенных птиц получают путем трансплантации предшественников половых клеток. Многие исследователи используют для этих целей и бластодермальные клетки, которые, будучи плюрипотентными, могут дифференцироваться как в соматические, так и в половые клетки [3]. К ранним недифференцированным клеткам относятся также первично-половые и эмбрионально-стволовые. Именно применение определенного типа клеток определяет конкретные методы получения химер птиц [4]. В начале 1990-х гг. появились первые сообщения о получении химер птиц при введении эмбриональных клеток [5]. Позднее стали получать как межпородные, так и межвидовые химеры птиц [6].

Цель данного исследования создание химер между породами брама светлая и брама палевая с учетом фенотипа полученных птиц и генетического расстояния между породами.

Материал и методика исследований. Из фондов биоресурсной коллекции ВНИИГРЖ 
«Генетическая коллекция редких и исчезающих пород кур» (Пушкин, Санкт-Петербург) были выбраны породы кур брама палевая и брама светлая. Проводили спаривание петухов с курами вышеуказанных пород. Яйца собирали, проверяли на овоскопе и определяли их оплодотворенность. У свежеснесенных яиц белки отделяли от желтков и вырезали бластодиски маленькими ножницами после накладывания кольца из фильтровальной бумаги. Эмбрионы-доноры отмывали от желтка, центрифугировали с добавлением культуральных сред, ресуспензировали и культивировали 2 суток в среде ДМЕМ с добавлением 10\% раствора фетальной бычьей сыворотки и антибиотиков. Эмбрионы-реципиенты находились в инкубаторе 2 суток при температуре $38^{\circ} \mathrm{C}$.

В яйцах реципиентов делали треугольные пропилы так, чтобы не повредить подскорлупные оболочки. С помощью микроманипулятора вводили суспензию клеток доноров. Далее отверстия в скорлупе заклеивали и помещали яйца в инкубатор до появления цыплят. Фенотип химер определяли по изменению окраски оперения в возрасте от суток до полугода. Генетическая дивергенция между породами была определена в работе [7] по методике [8], с помощью программы EIGENSOFT 6.1.4 методом Fst.

\section{Результаты исследований} и их обсуждение. Начальным этапом работы служил отбор пород с контрастной окраской оперения, что необходимо при создании химерных организмов, где основным доказательством химеризма служит измененный фенотип, полученный от генетического материала доноров.
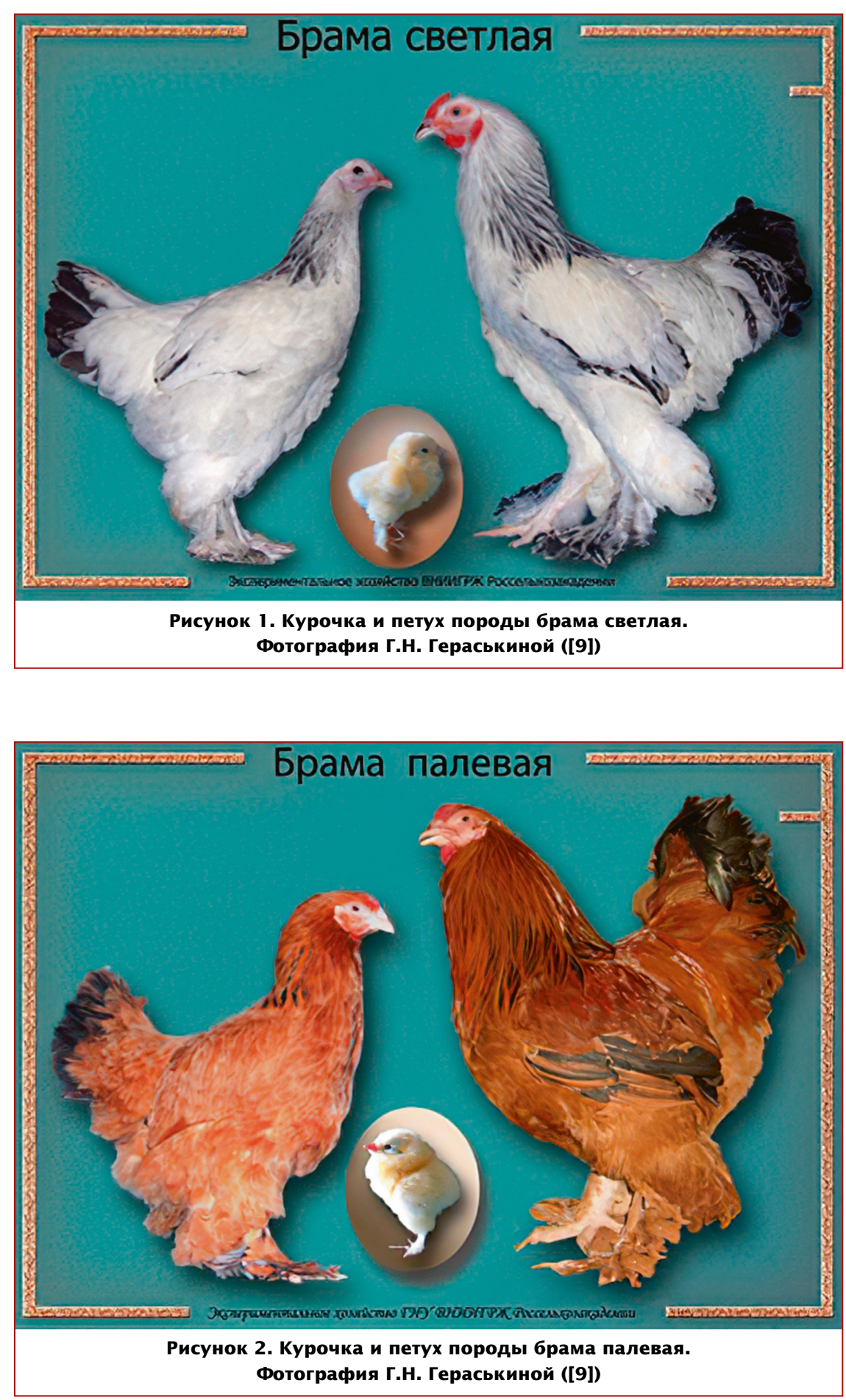

Брама светлая (рис. 1) выведена в США в середине XIX века на основе скрещивания кохинхинов, малайских бойцовых и, возможно, читтагонских кур. Брама ранее относилась к мясным породам. Теперь птица имеет мясодекоративное направление. Куры приносят за год до 120 яиц и достаточно неприхотливы и спокой- ны. Голова небольшая, с хорошо развитыми надбровными дугами и желтым клювом. Гребень небольшой, гороховидной формы, с четким разделением на три борозды. Гребень, мочки, лицо ярко-красные. Шея длинная с развитой гривой. Туловище массивное, кожа желтая. Хвост небольшой, раскинутый в стороны. Но- 
ги оперенные. Окраска оперения светлая. Отличается от брамы палевой наличием сцепленного с полом гена серебристой окраски S (Silver). Масса петухов - 4,0-5,0 кг, кур - 3,0-4,5 кг [9].

Брама палевая (рис. 2) имеет индийское происхождение и отселекционирована в США. Это декоративная, высокорослая, с широкой спиной и грудью птица с палевой окраской оперения, имеет доминантный ген Со (Columbian), ограничивающий местами черный цвет. Привлекательность этой породе придает ген лохмоногости (Pti-1). Средний и наружный пальцы оперены. Грива несколько темнее основного фона окраски. Петухи имеют небольшой гороховидный гребень. Оперение мягкое, с обильным пухом. Яйценоскость до 140 яиц. Окраска яиц - от желто-коричневого до желтокрасного цвета. Живая масса кур от 3,0 до 4,5 кг, петухов - от 3,5 до 5,0 кг [9].

В табл. 1 приведены данные о подборе групп пород брама светлая и брама палевая.
На овоскопе проверяли количество неоплодотворенных яиц. Выводимость контрольных групп птиц была довольно высокой и в среднем составляла 91,7\%, тогда как выводимость экспериментальных птиц в среднем составляла 48,35\%. Эти эмбрионы были инкубированы до стадии вылупления. Результаты инкубирования яиц с учетом замерших эмбрионов и полученных химер представлены в табл. 2.

Анализ результатов инкубации показал, что у экспериментальных групп птиц в среднем немногим меньше, чем из 50\% яиц вылупились цыплята. Часть яиц были не оплодотворены, и чуть больше 40\% цыплят погибли во время инкубации, что ожидаемо, т.к. реципиенты были подвергнуты пропилам скорлупы и процессу инъекции с помощью микроманипулятора. Наибольшее количество химер было показано при сочетании брама палевая - донор, брама светлая реципиент (42,9\%); тем не менее, при обратном сочетании этих же пород эффективность получения химерных особей была в 3 раза меньше. Причинами могли служить как технические сбои, так и особенности взаимодействия клеток разной генетической природы, объединенные в один организм.

Коэффициент дивергенции (Fst) между породами брама светлая и брама палевая соста-

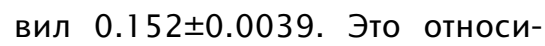
тельно большое генетическое расстояние по сравнению с другими породами, например, с породами суссекс и полтавская глинистая, у которых Fst равен $0.086 \pm 0.0020$ [7]. Возможно, генетическая дивергенция между породами не играет важную роль в эффективности получения химер. В среднем, эффективность получения химерных птиц в этой серии экспериментов составила $28,15 \%$.

Фенотипические особенности химерных птиц представлены на рис. 3-5.

Особенности фенотипа химерных птиц при сочетании брама светлая реципиент, брама палевая донор. Бласто-

\begin{tabular}{ccc} 
Таблица 1. Подбор двух пород кур, используемых для получения химер & \\
Номер породы & Название породы & Количество эмбрионов \\
\hline \multirow{2}{*}{19} & $\begin{array}{c}\text { Брама светлая } \\
\text { Контроль } \\
\text { Опыт }\end{array}$ & 6 \\
\hline \multirow{2}{*}{20} & $\begin{array}{c}\text { Брама палевая } \\
\text { Контроль } \\
\text { Опыт }\end{array}$ & 3 \\
\hline \multirow{2}{*}{ Всего } & Контроль & 14 \\
\hline
\end{tabular}

\begin{tabular}{|c|c|c|c|c|c|c|c|c|c|}
\hline \multirow{2}{*}{$\begin{array}{l}\text { Варианты } \\
\text { подбора }\end{array}$} & \multirow{2}{*}{$\begin{array}{c}\text { Инкубировано } \\
\text { яиц }\end{array}$} & \multicolumn{2}{|c|}{ Неоплодоворенных } & \multicolumn{2}{|c|}{ Замерших } & \multicolumn{2}{|c|}{ Выведено } & \multicolumn{2}{|c|}{ Химеры } \\
\hline & & $\mathbf{n}$ & $\%$ & $\mathbf{n}$ & $\%$ & $\mathbf{n}$ & $\%$ & $\mathbf{n}$ & $\%$ \\
\hline $\begin{array}{l}\text { БП - донор, } \\
\text { БС - реципиент }\end{array}$ & 14 & 2 & 14,3 & 4 & 35,7 & 7 & 50,0 & 6 & 42,9 \\
\hline $\begin{array}{l}\text { БС - донор, } \\
\text { БП - реципиент }\end{array}$ & 15 & 1 & 6,7 & 7 & 46,7 & 7 & 46,7 & 2 & 13,4 \\
\hline Итого & 29 & & & & & & & & \\
\hline
\end{tabular}




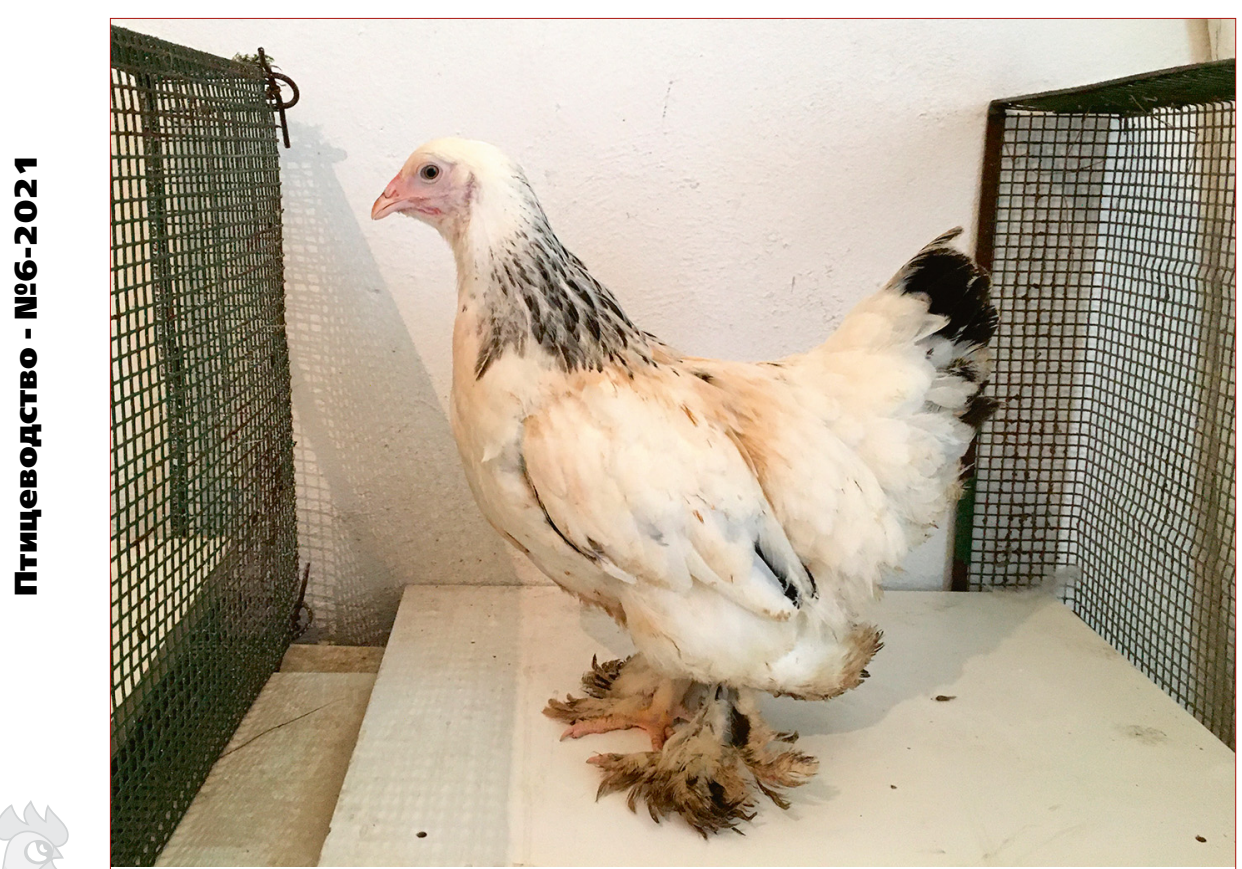

Рисунок 3. Химера: брама светлая реципиент, брама палевая донор. На спине и боках выявлены палевые перья

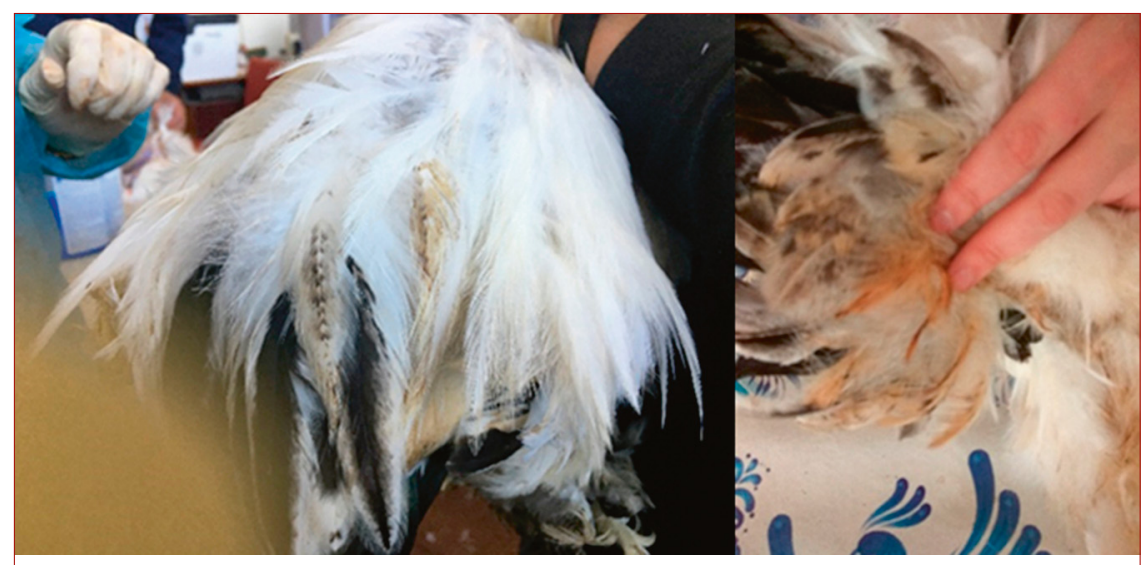

Рисунок 4. Химерные рыжие перья у брам светлых, полученные после трансплантации бластодермальных клеток брамы палевой

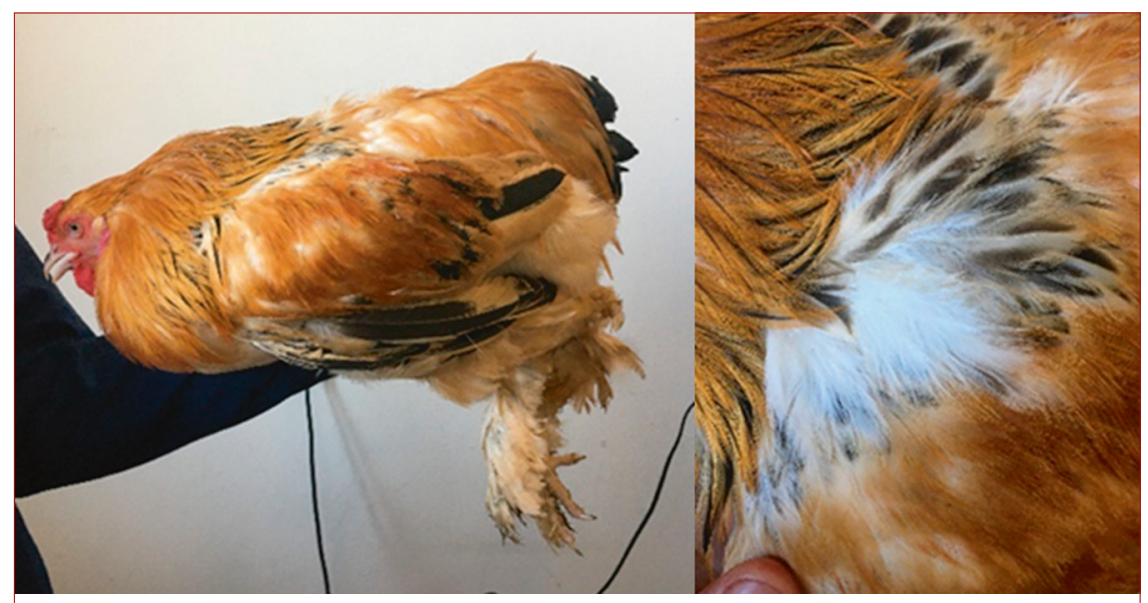

Рисунок 5. Химера: брама палевая реципиент, брама светлая донор дермальные клетки от брамы палевой трансплантировали в ранние эмбрионы брамы светлой. Были выявлены несколько химер с палевыми перьями. На рис. 3-4 представлены фенотипические особенности полученных птиц.

Особенности фенотипа химерных птиц при сочетании брама палевая реципиент, брама светлая донор. На рис. 5 отчетливо видны светлые белые перья от донора брамы светлой.

Таким образом, с помощью бластодермальных клеток были получены межпородные химеры птиц. Очевидно, что необходимы дальнейшие исследования в этом направлении т.к. химерные птицы могут быть промежуточным этапом для поиска путей создания трансгенных птиц с полезными генами.

Куры являются хорошо изученным объектом среди позвоночных, что позволяет интерпретировать полученные результаты для других видов птиц. Важную роль генетические химеры птиц могут сыграть при создании новых высокопродуктивных генотипов, а также при решении проблем, связанных с сохранением генетического разнообразия в популяциях птиц. Большое значение в биотехнологии имеет создание трансгенных птиц, несущих в своем геноме полезные свойства [10]. Технология получения химер часто используется как промежуточный этап получения генетически модифицированных птиц. Разработанный метод получения инъекционных химер кур может быть применен при проведении исследований в области экспериментальной эмбриологии, токсикологии, криобиологии и птицеводстве.

Заключение. Наши исследования показали, что метод 
получения иньекционных химер после трансплантации бластодермальных клеток реципиентам разных пород позволяет получать жизнеспособных химер кур с измененным фенотипом. Выводимость трансплантированных кур изменялась у этих пород от 46,7 до 50,0\%. Самая высокая эффективность получения химер была показана при сочетаниях брама светлая - реципиент, брама палевая - донор (42,9 \%). Получено 8 химер птиц и дана их фенотипическая характеристика.

Насмоящая рабома была Сыполнена 6 рамках государственного задания, № темб: 0445-2021-0010.

\section{Литература}

1. Muir W., Wong G.K., Zhang Y., Groenen M. [et al.] Genome-wide assessment of worldwide chicken SNP genetic diversity indicates significant absence of rare alleles in commercial breeds // Proc. Natl. Acad. Sci. USA. - 2008. - V.105. №45. - P.17312-17317.
2. Bednarczyk M., Kozłowska, I., Łakota, P. [et al.] Generation of transgenic chickens by the non-viral, cell-based method: effectiveness of some elements of this strategy // J. Appl. Genet. 2018. - V.59. - P. 81-89.

3. Wang Y.I., Brooks C.F., Jones S.A., Olliff L.K., Morgan M., Speksnijder G.L., Foley C., Harvey A.J. Progress toward the culture and transformation of chicken blastodermal cells // Stem Cells. - 2006. - V. 24, No 7. - P.16381645.

4. Козикова Л.В. Химеры птиц: методы получения и перспективы их использования. // Птицеводство. - 2019. №9. - С.9-13.

5. Carsience R.S, Clark M.E, Verrinder Gibbins A.M, Etches R.J.. Germline chimeric chickens from dispersed donor blastodermal cells and compromised recipient embryos // Development. 1993. - V. 117 , No 2. - P. 669-675.

6. Zhang W.X., Rui L., Zhang J., Yu X.X., Yan L., Zhang Z.F., Wan Z.Y., Shao Q., Qi C., Li Z.D. Production of chimeras between the Chinese soft-shelled turtle and Peking duck through transfer of early blastoderm cells // J. Exp. Biol. 2013. - V. 216, No 10. - P. 1786-1792.
7. Dementieva N.V., Kudinov A.A., Larkina T.A., Mitrofanova O.V., Dysin A.P., Terletsky V.P., Tyshchenko V.I., Griffin D.K., Romanov M.N. Genetic variability in local and imported germplasm chicken populations as revealed by analyzing runs of homozygosity // Animals (Basel). - 2020. - V. 10. - P.1887.

8. Patterson N., Price A.L., Reich D. Population structure and eigenanalysis // PLoS Genet. - 2006. - V. 2. - P.190.

9. Гераськина Г.Н, Юрченко О.П., Попов И.И., Вахрамеев А.Б., Толчинская Я.С., Паронян И.А. Альбом пород и популяций кур, сохраняемых и разводимых в «Экспериментальном хозяйстве ГНУ ВНИИГРЖ Россельхозакадемии». - Санкт-Петербург, Пушкин, 2009. - С. 98.

10. Kamihira M., Oguchi S., Tachibana A., Kitagawa Y., lijima S. Transgenic birds for the production of recombinant proteins // Adv. Biochem. Eng. Biotechnol. - 2004. - V. 91 - P.171-89.

\section{Для контакта с авторами:}

Козикова Лариса Васильевна

E-mail: larkozik@list.ru

Полтева Екатерина Андреевна

E-mail: ketlin.liselse@yandex.ru

\title{
Creation of Phenotypic Chimeras of Chickens using Blastodermal Cells of Brama Light and Brama Fawn Breeds
}

\author{
Kozikova L.V., Polteva E.A. \\ Russian Research Institute of Farm Animal Genetics and Breeding - \\ Branch of the L.K. Ernst Federal Research Center for Animal Husbandry
}

\begin{abstract}
Summary: The development of cell engineering and gene technologies makes it possible to obtain genetically new organisms, promote the diversity of breeds, and create unique chimeric and transgenic birds. By the method of transplantation of embryonic cells the interbreed chimeras of Brama Light (BL) and Brama Fawn $(B F)$ breeds were obtained. The largest number of chimeras was found with the combination BF as donor and $B L$ as recipient (42.9\%), while with the reversed combination of the same breeds the efficiency of chimerization was 3-fold lower. This difference could result from possible technical failures as well as from the peculiarities of the interaction of cells of different genetic nature combined into a single organism. On average, the efficiency of chimerization in this series of experiments was $28.15 \%$. The phenotypic characteristics of the chimeras obtained are presented. The developed method for the chimerization of chickens by injection can potentially be used in experimental embryology, cryobiology, transgenesis, veterinary medicine and poultry farming.
\end{abstract}

Keywords: chimeras, donors, recipients, chicken breeds, transplantation, blastodermal cells, phenotype. 